\section{Journal of Anatolian Environmental and Animal Sciences (Anadolu Çevre ve Hayvancılık Bilimleri Dergisi) Doi: https://doi.org/10.35229/jaes.636982}

\title{
Antioxidant, Antimicrobial and Anti-Quorum Sensing Activities of Usnea filipendula and Viscum album ${ }^{[*]}$
}

\author{
Sibel YILDIZ*1 Ayşenur GÜRGEN ${ }^{1}$ Ceyhun KILIÇ ${ }^{2}$ Sana TABBOUCHE $^{3}$ Ali Osman KILIÇ Zehra CAN $^{4}$ \\ ${ }^{1}$ Karadeniz Technical University, Department of Forestry Engineering, Trabzon, Turkey. \\ ${ }^{2}$ Department of Non-Forest Products, Eastern Karadeniz Forestry Research Institute, Trabzon, Turkey. \\ ${ }^{3}$ Karadeniz Technical University, Department of Medical Microbiology, Kanuni Campus, 61080 Trabzon, Turkey. \\ ${ }^{4}$ Bayburt University, Faculty of Science, Department of Emergency aid and Disaster, Bayburt, Turkey. \\ (D): https://orcid.org/0000-0001-8448-4628, (iD: https://orcid.org/0000-0002-2263-7323, (D): https://orcid.org/0000-0001-9412-2946 \\ (D): https://orcid.org/0000-0003-2072-4594, (iD: https://orcid.org/0000-0002-5506-0866, (iD: https://orcid.org/0000-0002-7156-4941
}

How to cite: Yildiz, S., Gürgen, A., Kiliç, C., Tabbouche, S., Kiliç, A.O. \& Can Z. (2019). Antioxidant, Antimicrobial and Anti-Quorum Sensing Activities of Usnea filipendula and Viscum album. Anatolian Env. and Anim. Sciences, 4(4), 613-620.

Atıf yapmak için: Yildiz, S., Gürgen, A., Kiliç, C., Tabbouche, S., Kiliç, A.O. \& Can Z. (2019). Usnea filipendula ve Viscum album'un Antioksidant, Antimikrobiyal ve Çoğunluğu Algılama İnhibisyonu Aktiviteleri. Anadolu Çev. ve Hay. Dergisi, 4(4), 613-620.

\begin{abstract}
Many plants contain a variety of bioactive components. Therefore, it is important to know the bioactive properties of plant materials in order to be a reference for later researchers. In this study, it was investigated the antioxidant, antimicrobial and anti-quorum sensing activities of Usnea filipendula and Viscum album's methanol extracts. To determine the antioxidant properties of the extracts; total phenolic, flavonoid and condensed tannin contents and ferric reducing antioxidant power analyses were performed. The antibacterial potential of plant extracts was tested by agar well diffusion method against Staphylococcus aureus, Escherichia coli, Enterococcus faecalis, Pseudomonas aeruginosa, Salmonella typhimurium, Klebsiella pneumoniae, Proteus mirabilis, Listeria monocytogenes, Candida parapsilosis and Candida albicans microorganisms. Anti-quorum sensing activity was investigated on Chromobacterium violaceum bacteria. The highest total phenolic and ferric reducing antioxidant power was determined in $U$. filipendula extract. This extract inhibited the growth of $S$. aureus, K. pneumonia and L. monocytogenes microorganisms. The highest flavonoid and condensed tannin was observed in $V$. album extract. This extract was also able to prevent the growth of $K$. pneumonia and L. monocytogenes. None of the extracts showed anti-quorum sensing activity.
\end{abstract}

Keywords: Antioxidant, antimicrobial anti-quorum sensing, Usnea filipendula, Viscum album.

\section{Usnea filipendula ve Viscum album'un Antioksidant, Antimikrobiyal ve Çoğunluğu Algılama İnhibisyonu Aktiviteleri}

Öz: Birçok bitki çeşitli biyoaktif bileşenler içerir. Bu nedenle, daha sonraki araştırmacılar için referans olması amacıyla bitki materyallerinin biyoaktif özelliklerini bilmek önemlidir. Bu çalışmada, Usnea filipendula ve Viscum album ün metanol ekstrelerinin antioksidan, antimikrobiyal ve çoğunluğu algılama inhibisyonu aktiviteleri incelenmiştir. Ekstraktların antioksidan özelliklerini belirlemek için; toplam fenolik, flavonoid ve kondanse tanen içerikleri ve demir indirgeyici antioksidan gücü analizleri yapılmıştır. Bitki ekstraktlarının antibakteriyel potansiyeli, Staphylococcus aureus, Escherichia coli, Enterococcus faecalis, Pseudomonas aeruginosa, Salmonella typhimurium, Klebsiella pneumoniae, Proteus mirabilis, Listeria monocytogenes, Candida parapsilosis ve Candida albicans mikroorganizmalarına karşı agar kuyucuk yöntemi ile ölçülmüştür. Chromobacterium violaceum bakterileri üzerinde ise çoğunluğu algılama inhibisyonu aktivitesi araştırılmıştır. En yüksek toplam fenolik ve demir indirgeyici antioksidan gücü, $U$. filipendula özütünde belirlenmiştir. Bu özüt, S. aureus, K. pneumonia ve $L$. monocytogenes mikroorganizmalarının büyümesini inhibe etmiştir. En yüksek flavonoid ve kondanse tanen $V$. album ekstraktında gözlenmiştir. $\mathrm{Bu}$ ekstre, K. pneumonia ve L. monocytogenes'in büyümesini önleyebilmiştir. Ekstraktların hiçbiri çoğunluğu algılama mekanizmasını inhibe edememiştir. 


\section{INTRODUCTION}

The plants can be described as 'a gift of nature' because they are therapeutic. Many kinds of them have played an active role in the treatment of different diseases for centuries (Farombi, 2003). Although many drugs or medical methods have been applied to treat diseases by the development of technology and science, some governments have made it compulsory to consume natural products for many aims (Ertürk et al., 2004). Plants produce secondary metabolites in their bodies and it has been proven by many scientific studies that secondary metabolites have antioxidant, antimicrobial, anticancer, antidiabetic, etc. properties (Rao \& Kingston, 1982; Mensor et al., 2001; Srinivasan, 2005; González-Lamothe et al., 2009; Kılıçkaya Selvi et al., 2019).

Some chemical reactions in body tissues produce free radical molecules under certain conditions. Free radicals occur naturally in every step of the duration. These molecules cause metabolic problems and play a role in bringing damage to tissues. However, these unstable electron-laden chemicals are largely destroyed or removed by natural antioxidant defence systems normally found in the body. The use of antioxidant plants/foods supports the body's antioxidant defence mechanism (Gate et al., 1999; Srinivasan, 2005). Antioxidants can be considered as two major groups; synthetic and natural, generally. Despite the synthetic ones have been used in many places, there is still suspicion about their reliability (Ho \& Shahidi, 2005; Taghvaei \& Jafari, 2015) because of their possible toxic/side effects especially during long-term intake (Taghvaei \& Jafari, 2015). On the other hand, it has been indicated that many natural additives have more antioxidants property and thermal stability than the synthetic ones.

Increased technology, unlimited consumption demand and pollution have also increased/diversified the disease. As it is known some plants species have been used to overcome the microorganisms that cause diseases. The therapeutic effects of plants are related to the synergistic effect of a large number of compounds. It has been reported that the herbal combinations provide more effective treatment against the resistance of microorganisms that are difficult to kill with a single antibiotic (Sree et al., 2010; Nazri et al., 2011).

While quorum sensing (QS) is the communication system between the bacterial cells by the signaling molecules, anti-quorum sensing is the name of the stopping this communication mechanism (Alvarez et al., 2012). Over the past few years, QS has become a very extensive field of research because of its promising results for the utilizations in industry, medicine and biotechnology (Taganna et al., 2011). According to research of some scientists that "plants are rich natural resource of quorum sensing agents" (Choo et al., 2006; Kohand Tham, 2011; Mohamed et al., 2014; AlHaidari et al., 2016). The most likely benefit of the QS researchers is to disrupt the signal communication between microorganisms' communities and to keep their growth under control. It was seen that there is not much study in the literature about the quorum sensing-disrupting activity of plants. Therefore, this study will reveal whether the lichen and mistletoe plants investigated in this article have antiquorum sensing activity or not.

It has been known that the lichens and mistletoe have some special bioactive properties. Bioactive natural products obtained from lichens have been utilized for medicinal and cosmetic purposes. Six lichen species involving usnic acid in various amounts were found to be effective against various (Cansaran et al., 2006; Y1ldı, 2017). On the other hand, biologically active components of mistletoe have been reviewed (Ochocka and Piotrowski, 2002). Ertürk et al. (2004) investigated anti-microbial properties of mistletoe (Viscum album L.) against a fungus and six bacteria species. They explained that different concentration of $n$-hexane extract of mistletoe was effectual against micro-organisms analyzed.

The phenolic components of plant origins have attracted attention because of their useful and nutritional properties including antioxidant and antimicrobial capacity, in recent years (Bubonja-Sonje et al., 2011). The plants that are found in abundant quantities and inexpensive such as lichen or mistletoe need to be investigated, firstly. In this study it was examined the antioxidant, antimicrobial and antiquorum sensing activities of Usnea filipendula and Viscum album's methanol extracts.

\section{MATERIAL and METHODS}

Lichen (Usnea filipendula) was collected from wild areas in Trabzon province, Tonya district (Fig. 1). Mistletoe (Viscum album L.) was collected from Pinus sylvestris host tree in Trabzon province, Sürmene district (Fig. 2), located in the north-eastern of Turkey (Table 1). The plants were brought to laboratory for extraction process.

Table 1. Investigated plant samples.

\begin{tabular}{llll}
\hline \multirow{2}{*}{ Sample } & \multirow{2}{*}{ Scientific classification } & \multicolumn{2}{c}{ Collected place } \\
\cline { 3 - 4 } & & Province & District \\
\hline Mistletoe & Viscum album L. & Trabzon & Tonya \\
\multirow{2}{*}{ Lichen } & Usnea filipendula & Trabzon & Sürmene \\
\hline
\end{tabular}

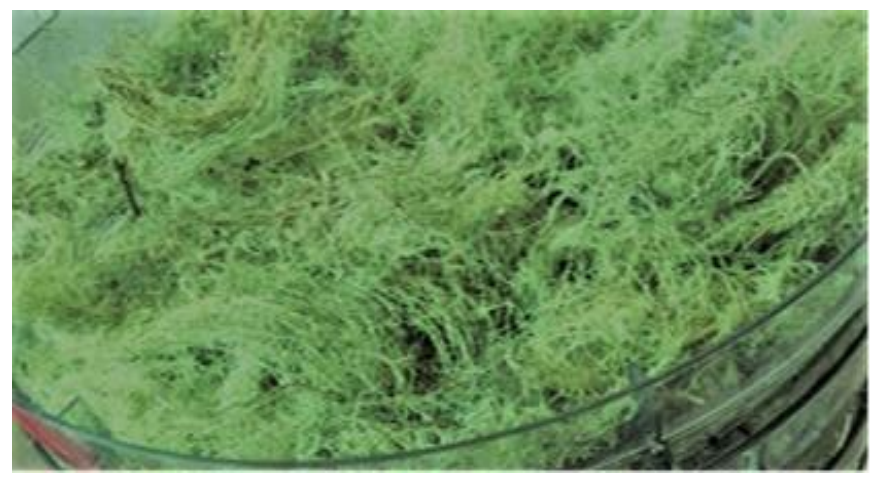

Figure 1. Lichen (Usnea filipendula) 


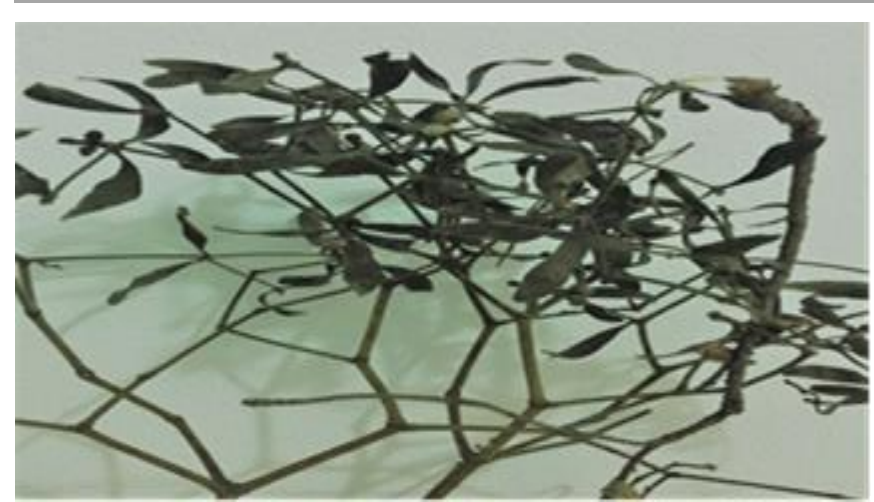

Figure 2. Mistletoe (Viscum album)

Sample Preparation: Whole of lichen and twigs of mistletoe were used for the analyses. Samples were dried in an oven at $60^{\circ} \mathrm{C}$ at 24 hours before grinding. A laboratory scale Wiley mill was utilized to grind. Approximately $5 \mathrm{~g}$ powdered samples were dissolved in $50 \mathrm{~mL}$ methanol (99\%). The mixture was continuously stirred using a shaker (Heidolph Promax 2020, Schwabach, Germany) at room temperature for $24 \mathrm{~h}$. Particles were removed using Whatman No. 4 filter paper (pore size 20-25 $\mu \mathrm{m}$ ). Then the solutions were filter sterilized using $0.45 \mu \mathrm{m}$ hydrophilic polyvinylidene fluoride (PVDF) filters.

\section{Antioxidant Properties}

Ferric Reducing Antioxidant Power (FRAP): The antioxidant capacity was determined using ferric reducing antioxidant power (FRAP). This method is based on the reduction of tripyridyltriazine complex $\left(\mathrm{Fe}(\mathrm{TPTZ})^{3+}\right)$ to blue colored $\mathrm{Fe}(\mathrm{TPTZ})^{2+}$ by antioxidants in acidic medium (Benzie and Strain, 1996). FRAP values were expressed in wet weight of the samples as $\mu$ mol of ferrous equivalent $\mathrm{Fe}$ (II) per g of sample.

Determination of Phenolic Contents: The polyphenolic contents of the methanol extracts were evaluated by three different ways; total phenolic contents (TPC), total flavonoids (TF) and condensed tannin (CT) contents. For the determination of the total phenolic contents, the Folin-Ciocalteau procedure was employed and gallic acid was used as standard (Slinkard \& Singleton, 1977). The results were expressed as mg Gallic Acid Equivalent (GAE) per $\mathrm{g}$ of methanolic extracts.

Determination of Flavonoid Contents: The concentration of the total flavonoid content in the methanol extracts was measured using a spectrometric assay. The total flavonoid concentration was expressed as mg equivalents of quercetin (QE) per g of sample (Fukumoto \& Mazza, 2000).

Determination of Condensed Tannins Contents: The concentration of condensed tannins was determined according to the method previously used by Julkunen-Titto (Julkunen-Tiitto, 1985). The results were expressed as mg catechin equivalent (CE) per $\mathrm{g}$ of sample.

Antimicrobial Activity: The extracts were tested for antimicrobial activity by agar-well diffusion method according to the Clinical \& Laboratory Standards Institute (CLSI) guidelines (Wayne, 2002) against Staphylococcus aureus ATCC 25923, Escherichia coli ATCC 25922, Enterococcus faecalis ATCC 29212, Pseudomonas aeruginosa ATCC 27853, Salmonella typhimurium ATCC 14028, Klebsiella pneumoniae ATCC 13883, Proteus mirabilis ATCC 7002, Listeria monocytogenes ATCC 43251, Candida parapsilosis ATCC 22019 and Candida albicans ATCC 10231. The microorganisms were obtained from Department of Medical Microbiology, Faculty of Medicine, Karadeniz Technical University, Trabzon, Turkey. Bacteria and yeast were cultured in Luria Bertani (LB) and Sabouroud Dextrose agar (LABM, UK), respectively. Fresh cultures (18 h) of bacteria and yeast were used to make suspension in 5 $\mathrm{mL}$ of sterile isotonic sodium chloride and turbidity was adjusted to $0.5 \mathrm{McF}$ arland. Agar plates were filled with suspension and $0.6 \mathrm{~cm}$ agar wells were cut out using a sterile pipette tip. 50 microliters of extracts were transferred into each agar well and cultures were incubated at $37^{\circ} \mathrm{C}$ for 24 hours. Ampicillin, gentamicin, cefotaxime, tetracycline and amphotericin B solutions and DMSO were used as positive and negative controls, respectively. The antimicrobial activity was determined by visual inspection and measurement of the diameter of inhibition zones around the agar-wells. The minimal inhibitory concentration (MIC) of the extracts showing a positive antimicrobial activity was determined using the liquid microdilution test method. The well with the lowest concentration that did not show any microbial growth was considered to be the MIC of the tested extract.

Anti-Quorum Sensing Activity: Anti-quorum sensing activity was determined using microdilution method as described for the antimicrobial activity test above (Damte et al., 2013). The anti-QS activity of the extracts has been tested against Chromobacterium violaceum ATCC 12472, a violacein-producing strain. Briefly, MIC of each extract was determined as described above and sub-MIC concentrations were used for the inhibition of pigment production of $C$. violaceum. For anti-QS assay, to the fresh culture of the strains in LB broth was added for each extract and incubated for $24 \mathrm{~h}$. At the end of the incubation, $1 \mathrm{~mL}$ of culture was centrifuged and pellet was resuspended in $1 \mathrm{ml}$ of DMSO and vortexed at the high speed for pigment extraction. Supernatant was removed and absorbance values of the pigments were determined at OD $585 \mathrm{~nm}$ using a microplate reader (Damte et al., 2013; Norizan et al., 2013). Vanilla extract was used as positive control (Choo et al., 2006).

Statistical Analysis: The data were presented as means and standard deviations of three replicates for total phenolic content and antioxidant properties and ten replicates for metal composition analyzed by using Statistical Package for Social Sciences (SPSS version 23.0). The data were analyzed by ANOVA and tests of statistical significance were performed using Duncan's multiple range tests. 


\section{RESULTS and DISCUSSION}

Antioxidant Activity: In this study, antioxidant capacity was determined using ferric reducing antioxidant power (FRAP) method. The results are given Figure 3.

As shown in Figure 3, antioxidant capacity of $U$. filipendula $\left(54.4 \mu \mathrm{molFeSO}_{4} .7 \mathrm{H}_{2} \mathrm{O} / \mathrm{g}\right)$ was found higher than antioxidant capacity of $V$. album $\left(51.45 \mu \mathrm{molFeSO}_{4} \cdot 7 \mathrm{H}_{2} \mathrm{O} / \mathrm{g}\right)$. Vicas et al. (2009) investigated the hydrophilic and lipophilic antioxidant activities of $V$. album. For this purpose, they collected the $V$. album leaves and stems from five host trees (Acer campestre, Malus domestica, Fraxinus excelsior, Populus nigra and Robinia pseudoacacia) and determined the antioxidant activity of methanol and acetone extracts of all collected samples. They reported that methanol extract of $V$. album leaves collected from $M$. domestica exhibited the highest activity.

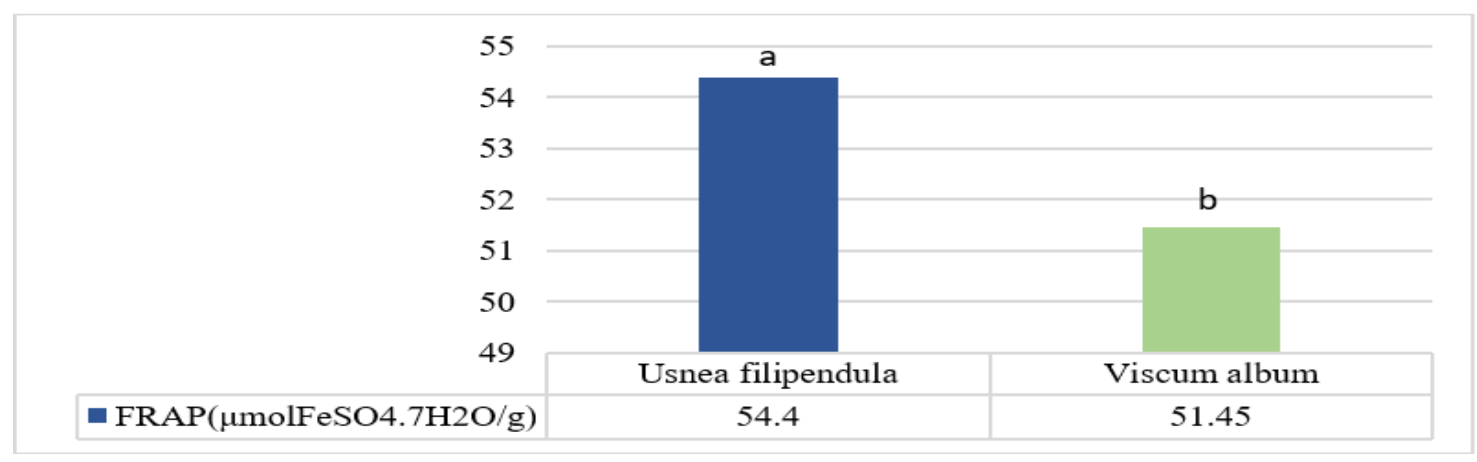

Figure 3. Antioxidant capacity of samples

Önay-Uçar et al. (2006) found that V. album living in different trees had different antioxidant activity. So, they reported that $V$. album extract's antioxidant capacity can vary depending on the plant's harvest time and the configuration of the main tree at the same time. In this study, V. album was collected from $P$. sylvestris host tree. Therefore, it can be concluded that antioxidant capacity of $V$. album collected from different host tree can be differ from our results. In a study, the reducing power activity of $V$. album crude alcoholic extract was reported at 0.10 equivalent $1 \mathrm{mM} \mathrm{FeSO}_{4}$ by (Papuc et al., 2010). It was noticed that extracts of $V$. album obtained from cashew tree demonstrated a stronger $\mathrm{Fe}$ chelating ability (Oluwaseun \& Ganiyu, 2008).

Oran et al. (2016) studied the antioxidant capacity of different lichen species' (Usnea intermedia, Usnea filipendula and Usnea fulvoreagens) methanol and ethanol extracts. They reported that methanol extracts of lichen species showed higher antioxidant capacity from the ethanol extracts.

All the previous studies and the present study are evaluated together, it can be concluded that the antioxidant capacity is affected many factors such as extract type and method, extract concentration, plant harvesting time, host tree (for mistletoe) etc.

Total Phenolic Contents: In this study, the polyphenolic contents of the methanol extracts were evaluated by three different ways; total phenolic content, total flavonoids and condensed tannin contents. The polyphenolic contents of the methanol extracts of samples are given in Figure 4.

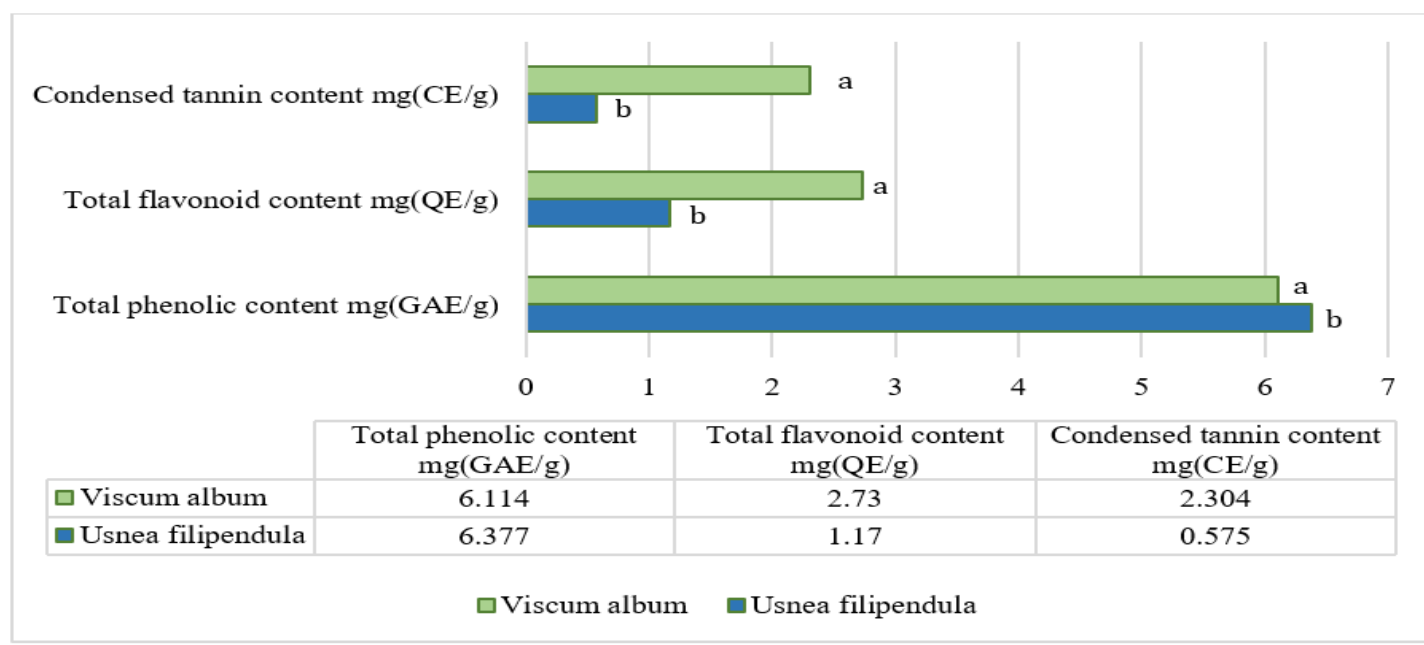

Figure 4. The polyphenolic contents of the methanol extracts of samples. 
In this study, total phenolic contents of $V$. album and $U$. filipendula was determined as 6.114 and $6.377 \mathrm{mg}(\mathrm{GAE}) / \mathrm{g}$, respectively (Fig. 4) and the results were found to be statistically significant each other $(\mathrm{p}<0.05)$.

In a study, total phenolic contents of $V$. album methanol extract were determined as $19.43 \mathrm{mg} \mathrm{GAE} / \mathrm{g}$ dried weight (Sengul et al., 2009). Vicas et al. (2009) reported that the total phenolic content of $V$. album methanolic and acetonic extracts' which collected from 5 host tree were between $0.40-0.65 \mathrm{mg} \mathrm{GAE} / \mathrm{g}$ fresh weight and $0.002-0.015 \mathrm{mg} \mathrm{GAE} / \mathrm{g}$ fresh weigh, respectively. It can be concluded that the total phenolic content of the mistletoe collected from different host trees is also different. (Papuc et al., 2010) informed that the polyphenols of $V$. album ethanolic extracts as 6.33 $\mathrm{mg} / \mathrm{g}$ dry plant. Our results are comparable with just mentioned study. Total phenolic content of U. filipendula acetone, ethanol and methanol extracts was reported that 329.7, 197.4 and $291.5 \mathrm{mg}$ GAE/100 g-1 of dried lichen, respectively (Oran et al., 2016).

Total Flavonoid Contents: In this study, total flavonoid content of V. album and U. filipendula was calculated as 2.73 and
$1.17 \mathrm{mg}(\mathrm{QE} / \mathrm{g})$, respectively (Fig. 4). In a previous study, it was (Papuc et al., 2010) reported that the flavonoid content of $V$. album ethanolic extracts was $9.72 \mathrm{mg} / \mathrm{g}$ dry plant. It can be said that the solvent type affects the flavonoid content. There are some studies in the literature reported that some lichen species have important flavonoid contents (Kosanić et al., 2011).

Condensed Tannins Contents: In this study, condensed tannin content of $V$. album extract $(2.304 \mathrm{mg}(\mathrm{CE} / \mathrm{g}))$ was found 4 times higher than the $U$. filipendula extract $(0.575 \mathrm{mg}(\mathrm{CE} / \mathrm{g})$.

When all the polyphenolic contents and antioxidant capacity of methanol extracts of studied samples are evaluated together, the higher total phenolic content and antioxidant capacity was determined in $U$. filipendula extract while the higher total flavonoid content and condensed tannin content was determined in V. album extract.

Antimicrobial Activity: The antimicrobial activity of studied samples and used antibiotics are given Table 2.

Table 2. Antimicrobial activity and used antibiotics

\begin{tabular}{|c|c|c|c|c|c|c|c|}
\hline \multirow{2}{*}{ Bacteria isolates } & \multicolumn{7}{|c|}{ Agar Well Diffusion (mm zone diameter) } \\
\hline & V. album & U. filipendula & Ampicillin & Gentamicin & Amphotericin B & Tetracycline & Cefotaxime \\
\hline S. aureus & 0 & 4 & $>30$ & - & - & - & - \\
\hline E. coli & 0 & 0 & $16-17$ & - & - & - & - \\
\hline P. aeruginosa & 0 & 0 & - & $21-22$ & - & - & - \\
\hline E. faecalis & 0 & 0 & $>30$ & - & - & - & - \\
\hline C. albicans & 0 & 0 & - & - & 30 & & \\
\hline C. parapsilosis & 0 & 0 & - & - & - & - & - \\
\hline S. typhimurium & 0 & 0 & 27 & - & - & - & - \\
\hline P. mirabilis & 0 & 0 & - & - & - & - & 37 \\
\hline K. pneumoniae & 2 & 1 & - & - & - & - & - \\
\hline L. monocytogenes & 2 & 1 & - & - & - & 25 & - \\
\hline
\end{tabular}

As can be seen in Table 2, V. album methanol extract inhibited $K$. pneumoniae, L. monocytogenes and $U$. filipendula methanol extract inhibited $S$. aureus, $K$. pneumoniae and L. monocytogenes microorganisms. Also, $V$. album extract was shown better antimicrobial zone than $U$. filipendula extract against $K$. pneumoniae and $L$. monocytogenes microorganisms.

Minimum inhibition concentration (MIC) values of extracts which show antimicrobial property are given in Table 3.

Table 3. Minimum inhibition concentration (MIC) values of extracts $(\mu \mathrm{g} / \mathrm{mL})$.

\begin{tabular}{lcc}
\hline Bacteria used in the test & V. album & U. filipendula \\
\hline S. aureus & - & 312.5 \\
K. pneumoniae & 1250 & 1250 \\
L. monocytogenes & 625 & 625 \\
\hline
\end{tabular}

The lower MIC value means the stronger antimicrobial effect of extract. In this study, U. filipendula methanol extract has the best antimicrobial activity against $S$. aureus microorganism with $312.5 \mu \mathrm{g} / \mathrm{mL}$ concentration. It can be said that $V$. album extract was more effective than $U$. filipendula extract, because when same MIC values of extract was tested (Table 3), V. album extract showed higher (twice times) antimicrobial activity ( $\mathrm{mm}$ zone diameter) from $U$. filipendula extract (Table 2).

Sengul et al. (2009) reported that both methanol and aqueous extracts of $V$. album inhibited many organisms. Methanol extracts showed better antimicrobial activity than aqueous extracts. In a study, it was investigated the antimicrobial activity of different extracts (acetone, petroleum ether, ethyl acetate, chloroform, ethanol, methanol, water) of $V$. album collected from Rialy, Muzaffarabad Azad Jammu and Kashmir. According to the reported results all extracts inhibited many of studied microorganisms except from acetone and petroleum ether extracts (Hussain et al., 2011). In another study; it was investigated that antimicrobial activity of $V$. album against 6 bacteria and 1 fungus (Bacillus subtilis, Staphylococcus aureus, Escherichia coli, Pseudomonas aeruginosa, Enterobacter cloacae, Proteus vulgaris and Candida albicans). The results showed that the 
different concentrations of $n$-hexane extract of mistletoe were effective against micro-organisms analyzed (Ertürk et al., 2003).

Oran et al. (2016) reported that the MIC values of all analyzed extracts ranged from $64 \mu \mathrm{g} / \mathrm{mL}$ to $512 \mu \mathrm{g} / \mathrm{mL}$ for all the bacterial strains and all the Fluoro quinolone-resistant Escherichia coli isolates (except for E101) were sensitive to the methanol extracts of the three Usnea filipendula. In another study, it was reported that $U$. filipendula have antimutagenic and antigenotoxic effects.

Antiquorum Sensing Activity: The communication mechanism between microorganisms has called "quorum sensing" (QS). Anti-QS activity charts of positive control (vanilla) and $U$. filipendula and V. album are given Figure 57 , respectively.

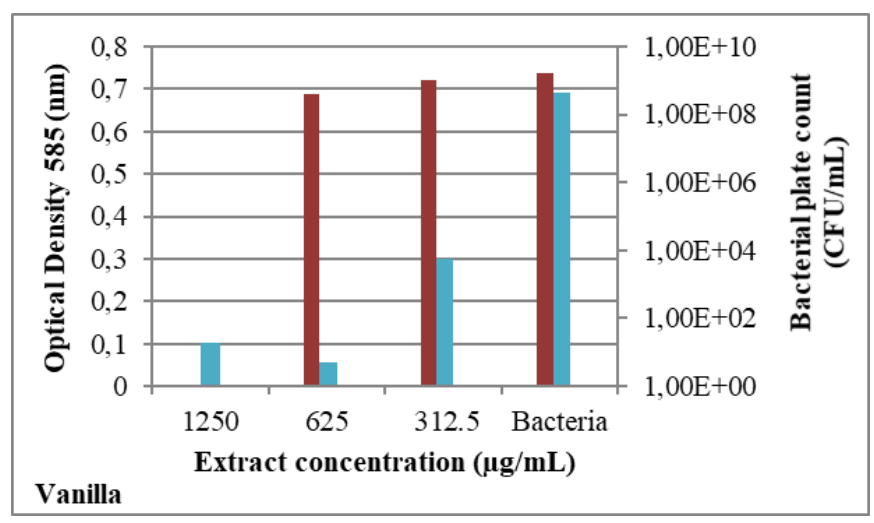

Figure 5. Anti-QS activity chart of vanilla.

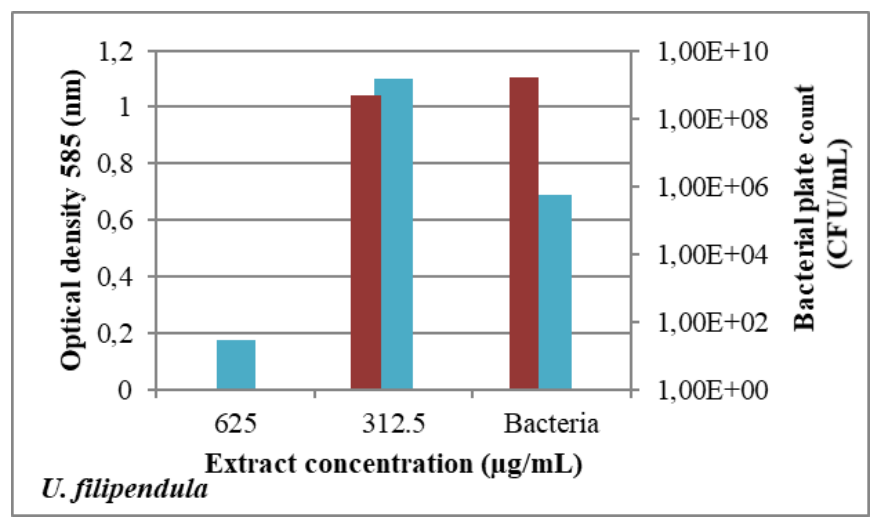

Figure 6. Anti-QS activity chart of $U$. filipendula

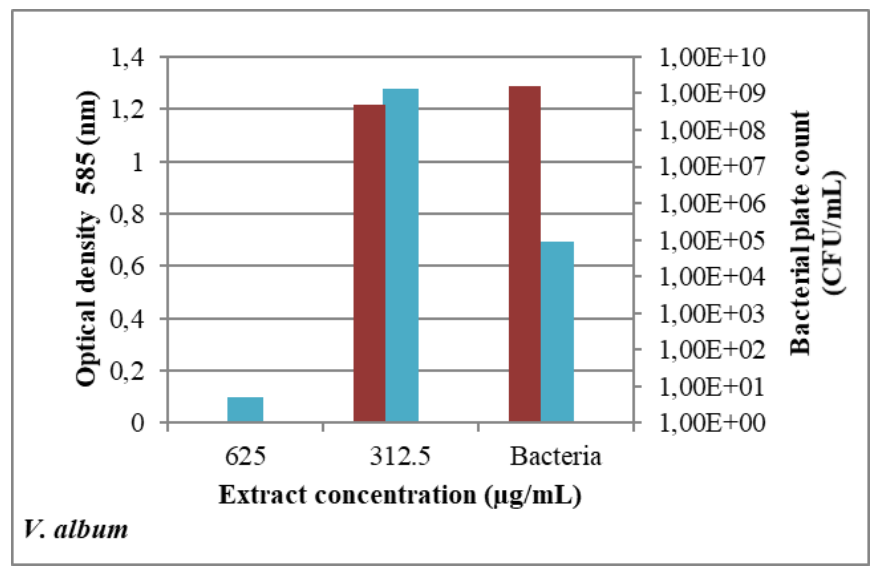

Figure 7. Anti-QS activity chart of V. album
Bacteria used in this study (C. violaceum) for antiQS assay produces the purple pigment. If the extract we use is not killing bacteria or killing very little, the intensity of pigment production is not reduce, or if it is very low, it can be considered that used extract have anti-QS activity. A good functioning of this mentioned state is seen in the positive control extract (Fig. 5). Vanilla showed anti-QS activity from 312.5 to $625 \mu \mathrm{g} / \mathrm{mL}$ while inhibited the bacteria when 1250 $\mu \mathrm{g} / \mathrm{mL}$. In this study, both of $U$. filipendula and $V$. album inhibited the $C$. violaceum at $625 \mathrm{Mg} / \mathrm{mL}$ extract concentration so they did not show anti-QS activity.

Kenar et al. (2016) investigated that the methanolic and dicloromethanolic extracts of fruits, leaves, and stem of V. album. They used agar well and disc diffusion assay for anti-QS activity using Chromobacterium violaceum (CV12472 and CVO26) strains. They reported that the effect of $V$. album extracts on anti-biofilm and anti-QS was very effective over biofilms produced by pathogens and these extracts were good sources for new antimicrobial components.

\section{CONCLUSION}

In this study antioxidant, antimicrobial and antiquorum sensing activities of $U$. filipendula and $V$ album's methanol extracts were investigated. As a result; the higher total phenolic content and antioxidant capacity was determined in $U$. filipendula extract. The higher total flavonoid content and condensed tannin content was determined in $V$. album extract. $U$. filipendula methanol extract has the best antimicrobial activity against $S$. aureus microorganism with $312.5 \mu \mathrm{g} / \mathrm{mL}$ concentration. $V$. album extract was more effective than $U$. filipendula extract against K. pneumoniae and L. monocytogenes. Both of extracts inhibited $C$. violaceum, they did not show anti-QS activity.

\section{ACKNOWLEDGEMENTS}

This work was supported by Karadeniz Technical University Scientific Research Projects Unit (FHD-20176018).

\section{REFERENCES}

Al-Haidari, R.A., Shaaban, M.I., Ibrahim, S.R. \& Mohamed, G.A. (2016). Anti-quorum sensing activity of some medicinal plants. African Journal of Traditional, Complementary \& Alternative Medicines, 13(5), 67-71.

Alvarez, M.V., Moreira, M.R. \& Ponce, A. (2012). Antiquorum sensing and antimicrobial activity of natural agents with potential use in food. Journal of Food Safety, 32(3), 379-387.

Benzie, I.F. \& Strain, J.J. (1996). The ferric reducing ability of plasma (FRAP) as a measure of 
"antioxidant power": the FRAP assay. Analytical Biochemistry, 239(1),70-76.

Bubonja-Sonje, M., Giacometti, J. \& Abram, M. (2011). Antioxidant and antilisterial activity of olive oil, cocoa and rosemary extract polyphenols. Food Chemistry, 127(4), 1821-1827.

Cansaran, D., Kahya, D., Yurdakulol, E. \& Atakol, O. (2006). Identification and quantitation of usnic acid from the lichen Usnea species of Anatolia and antimicrobial activity. Zeitschrift für Naturforschung C, 61(11-12), 773-776.

Choo, J., Rukayadi, Y. \& Hwang, J.K. (2006). Inhibition of bacterial quorum sensing by vanilla extract. Letters in Applied Microbiology, 42(6), 637-641.

Damte, D., Gebru, E., Lee, S., Suh, J. \& Park, S. (2013). Evaluation of anti-quorum sensing activity of 97 indigenous plant extracts from Korea through bioreporter bacterial strains Chromobacterium violaceum and Pseudomonas aeruginosa. Journal of Microbial and Biochemical Technology, 5(2), 42-46.

Ertürk, Ö., Kati, H., Yayli, N. \& Demirbağ, Z. (2004). Antimicrobial activity of Viscum album L. subsp. abietis (Wiesb). Turkish Journal of Biology, 27(4), 255-258.

Farombi, E.O. (2003). African indigenous plants with chemotherapeutic potentials and biotechnological approach to the production of bioactive prophylactic agents. African Journal of Biotechnology, 2(12), 662-671.

Fukumoto, L. \& Mazza, G. (2000). Assessing antioxidant and prooxidant activities of phenolic compounds. Journal of Agricultural and Food Chemistry, 48(8), 3597-3604.

Gate, L., Paul, J., Ba, G.N., Tew, K. \& Tapiero, H. (1999). Oxidative stress induced in pathologies: the role of antioxidants. Biomedicine \& Pharmacotherapy, 53(4), 169-180.

González-Lamothe, R., Mitchell, G., Gattuso, M., Diarra, M.S., Malouin, F. \& Bouarab, K. (2009). Plant antimicrobial agents and their effects on plant and human pathogens. International Journal of Molecular Sciences, 10(8), 3400-3419.

Ho, C.T. \& Shahidi, F. (2005). Flavor components of fats and oils. Bailey's industrial oil and fat products. Shahidi F. Ed., Doi: 10.1002/047167849X.bio009.

Hussain, M.A., Khan, M.Q. \& Hussain, N. (2011). Antimicrobial screening of Viscum album L. extracts. Paper presented at the 2nd International Conference on Environmental Science and Technology IPCBEE, 2011, Press, Singapore.

Julkunen-Tiitto, R. (1985). Phenolic constituents in the leaves of northern willows: methods for the analysis of certain phenolics. Journal of Agricultural and Food Chemistry, 33(2), 213-217.

Kenar, N., Erdonmez, D. \& Turkmen, K.E. (2016). Antiquorum sensing and anti-biofilm activity of Viscum album L. on different pathogenic bacteria. Journal of Biotechnology, 231, 34.

Kılıçkaya Selvi, E., Usta, A. \& Akıner, M.M. (2019). Larvacidal activity of some medicinal plants naturally growing in Turkey against Aedes albopictus (Diptera: Culicidae). Journal of Anatolian Environmental and Animal Sciences, 4(1), 53-59. Doi: https://doi.org/10.35229/jaes.530139.

Koh, K.H. \& Tham, F.-Y. (2011). Screening of traditional Chinese medicinal plants for quorum-sensing inhibitors activity. Journal of Microbiology, Immunology and Infection, 44(2), 144-148.

Kosanić, M., Ranković, B. \& Vukojević, J. (2011). Antioxidant properties of some lichen species. Journal of Food Science and Technology, 48(5), 584-590.

Mensor, L.L., Menezes, F.S., Leitão, G.G., Reis, A.S., dos Santos, T.C., Coube, C.S. \& Leitão, S.G. (2001). Screening of Brazilian plant extracts for antioxidant activity by the use of DPPH free radical method. Phytotherapy Research, 15(2), 127-130.

Mohamed, G.A., Ibrahim, S.R., Shaaban, M.I. \& Ross, S.A. (2014). Mangostanaxanthones I and II, new xanthones from the pericarp of Garcinia mangostana. Fitoterapia, 98, 215-221.

Nazri, N.M., Ahmat, N., Adnan, A., Mohamad, S.S. \& Ruzaina, S.S. (2011). In vitro antibacterial and radical scavenging activities of Malaysian table salad. African Journal of Biotechnology, 10(30), 5728-5735.

Norizan, S.N.M. Yin, W.-F. \& Chan, K.-G. (2013). Caffeine as a potential quorum sensing inhibitor. Sensors, 13(4), 5117-5129.

Ochocka, J.R. \& Piotrowski, A. (2002). Biologically active compounds from European mistletoe (Viscum album L.). Canadian Journal of Plant Pathology, 24(1), 21-28.

Oluwaseun, A.A. \& Ganiyu, O. (2008). Antioxidant properties of methanolic extracts of mistletoes (Viscum album) from cocoa and cashew trees in Nigeria. African Journal of Biotechnology, 7(17), 3138-3142.

Oran, S., Sahin, S., Sahinturk, P., Ozturk, S. \& Demir, C. (2016). Antioxidant and antimicrobial potential, and HPLC analysis of stictic and usnic acids of three usnea species from Uludag Mountain (Bursa, Turkey). Iranian Journal of Pharmaceutical Research: IJPR, 15(2), 527-535.

Önay-Uçar, E., Karagöz, A. \& Arda, N. (2006). Antioxidant activity of Viscum album ssp. album. Fitoterapia, 77(7-8), 556-560.

Papuc, C., Crivineanu, M., Goran, G., Nicorescu, V. \& Durdun, N. (2010). Free radicals scavenging and antioxidant activity of European mistletoe (Viscum album) and European birthwort (Aristolochia clematitis). Revista de Chimie, 61(7), 619-622. 
Rao, M.M. \& Kingston, D.G. (1982). Plant anticancer agents. XII. Isolation and structure elucidation of new cytotoxic quinones from Tabebuia cassinoides. Journal of Natural Products, 45(5), 600-604.

Sengul, M., Yildiz, H., Gungor, N., Cetin, B., Eser, Z. \& Ercisli, S. (2009). Total phenolic content, antioxidant and antimicrobial activities of some medicinal plants. Pakistan Journal of Pharmaceutical Sciences, 22(1), 102-106.

Slinkard, K.\& Singleton, V.L. (1977). Total phenol analysis: automation and comparison with manual methods. American Journal of Enology and Viticulture, 28(1), 49-55.

Sree, K.S., Yasodamma, N. \& Paramageetham, C. (2010). Phytochemical screening and in vitro antibacterial activity of the methanolic leaf extract: Sebastiania chamaelea muell. ARG. Bioscan, 5(1), 173-175.

Srinivasan, K. (2005). Plant foods in the management of diabetes mellitus: spices as beneficial antidiabetic food adjuncts. International Journal of Food Sciences and Nutrition, 56(6), 399-414.

Taganna, J.C., Quanico, J.P., Perono, R.M.G., Amor, E.C. \& Rivera, W.L. (2011). Tannin-rich fraction from Terminalia catappa inhibits quorum sensing (QS) in Chromobacterium violaceum and the QScontrolled biofilm maturation and LasA staphylolytic activity in Pseudomonas aeruginosa. Journal of Ethnopharmacology, 134(3), 865-871.

Taghvaei, M. \& Jafari, S.M. (2015). Application and stability of natural antioxidants in edible oils in order to substitute synthetic additives. Journal of Food Science and Technology, 52(3), 1272-1282.
Vicas, S., Prokisch, J., Rugina, D. \& Socaciu, C. (2009). Hydrophilic and lipophilic antioxidant activities of mistletoe (Viscum album) as determined by FRAP method. Notulae Botanicae Horti Agrobotanici Cluj-napoca, 37(2), 112.

Wayne, P. (2002). National committee for clinical laboratory standards. Performance standards for antimicrobial disc susceptibility testing, 12.

Yıldız, Ü.C., Kılıç, C., Gürgen, A. \& Yıldız, S. (2017). Possibility of using lichen (Usnea filipendula) and mistletoe (Viscum album L.) extracts as potential natural wood preservative. Paper presented at the IRG /WP 17- 30712. 48th IRG Annual Meeting, Ghent, Belgium.

*Corresponding author's:

Sibel YILDIZ

Karadeniz Technical University, Department of Forestry Engineering, Kanuni Campus, 61080, Trabzon, Turkey.

E-mail : sibelyildiz@ktu.edu.tr

ORCID : https://orcid.org/0000-0001-8448-4628

Phone : +90(462) 3771510

Fax : $+90(462) 3257499$

GSM : +90(532) 5747458 